\title{
Penggunaan Aerasi Air Mancur Ganda (double fountain) di Kolam untuk Meningkatkan Pertumbuhan Ikan Nila Gift (Oreochromis niloticus)
}

\author{
[Used of a Double Fountain Water Aeration in The Rearing Pond \\ to Improve Growth of Tilapia (Oreochromis niloticus)] \\ Ade Sunaryo ${ }^{\boxplus}$ \\ Jurusan Penyuluhan Perikanan - Sekolah Tinggi Perikanan \\ Jalan Cikaret Nomor 2 Bogor, Jawa Barat \\ Diterima: 20 Nopember 2015; disetujui: 15 Maret 2016
}

\begin{abstract}
Abstrak
Penelitian ini bertujuan untuk mengetahui perbedaan antara kolam yang menggunakan aerasi air mancur ganda (double fountain) dengan kolam tanpa aerasi untuk pertumbuhan dan kelangsungan hidup ikan nila gift. Penelitian dilaksanakan di kolam di areal Cikaret Kota Bogor. Metode penelitian yang digunakan adalah Uji t (t-test). Hasil penelitian didapatkan: nilai rata-rata pertumbuhan relatif berat (\%) pada perlakuan kolam aerasi air mancur ganda (A1) $(1835,98 \%)$, tanpa aerasi (A2) $(1352,29 \%)$. Rerata nilai faktor kondisi A1 $(3,66)$ dan A2 $(3,53)$. Rerata nilai konversi makanan A1 $(1,49)$ dan A2 (1,73). Rerata nilai kelangsungan hidup A1 $(91,67 \%)$ dan A2 $(89,17 \%)$. Hasil analisis uji $\mathrm{t}$ dari hasil semua parameter pengamatan antara kolam aerasi air mancur ganda (fountain) (A1) dengan tanpa aerasi (A2) menunjukan tidak berbeda nyata (menerima $\mathrm{Ho}$; tolak $\mathrm{H}_{1}$ ). Hasil analisis kualitas air masih berada dalam toleransi yang cukup baik untuk kehidupan ikan nila gift. Hasil analisa kepadatan plankton A1 (18.390 sel.liter $\left.{ }^{-1}\right)$ dan A2 ( 8.430 sel.liter $\left.^{-1}\right)$.
\end{abstract}

Kata kunci: double fountain, kolam, nila gift

\begin{abstract}
The objective of the research was to determine the difference between ponds using a double fountain aeration with no aerated ponds for growth and survival rate of tilapia. The research was carried out in Cikaret areal pond of Bogor district. The research method used is t test (t-test). The result showed that the average value of relative growth weight in the $(\%)$ on the treatment of experiment to aeration pond of double fountain was (A1) $(1835,98 \%)$, without aeration was (A2) (1352,29\%). Condition value rate was of A1 $(3,66)$ and A2 $(3,53)$. Food conversion ratio for A1 was $(1,49)$ and A2 was $(1,73)$. Survival rate for A1 was $(91,67 \%)$ and $\mathrm{A} 2$ was $(89,17 \%)$. The result of t-test analysis from the result of all observation parameters between aeration pond was (A1) with no aeration (A2) showed no significant difference (accept Ho; reject H1). Water quality analysis results are still in tolerance is good enough for the life of tilapia. Results of plankton density analysis A1 was $\left(18,390\right.$ cells.liters $\left.^{-1}\right)$ and A2 was $\left(8,430\right.$ cells.liters $\left.^{-1}\right)$.
\end{abstract}

Keyword: double fountain, rearing, pond, tilapia

\section{PENDAHULUAN}

Akhir-akhir ini produktivitas kolam ikan di sepanjang aliran irigasi Cikaret Kota Bogor dirasakan oleh para

$\triangle$ Penulis korespondensi

Alamat surel: adesunaryo@yahoo.com pembudidaya ikan semakin menurun.

Menurut penuturan salah seorang pembudidaya ikan, jika dulu dalam satu kolam ikan ukuran 20 m x 10 m yang ditebar 5.000 ekor ikan nila gift 
(Oreochromis niloticus) yang mampu berproduksi rata-rata 2-3 ton, sekarang dalam kondisi yang sama hanya mampu berproduksi $0,5-1$ ton. Hal ini diduga karena salah satu penyebabnya adalah semakin turunnya kemampuan daya dukung (carrying capacity) unit-unit perkolaman ikan tersebut. Karena daya dukung kolam yang berkurang, sehingga mortalitasnya sangat tinggi dan kecepatan tumbuhnya relatif rendah. Hal ini diduga akibat, rendahnya kadar oksigen terlarut, terutama pada malam hari. masalah ini, perlu adanya pemikiran aerasi yang memanfaatkan gaya gravitasi dari beda ketinggian air permukaan irigasi dengan air kolam. Dengan adanya model teknologi aerasi air mancur ganda ini diharapkan dapat diterapkan pada pembudidayaan ikan, khususnya di perkolaman beririgasi Cikaret Bogor.

\section{BAHAN DAN METODE}

Penelitian ini dilaksanakan di kolam Cikaret Kota Bogor. Benih nila gift yang telah diaklimatisasi ditebar dengan ukuran rata-rata panjang $6 \mathrm{~cm}$ dan berat $3,28 \mathrm{~g}$. Padat penebaran per hapa 60 ekor dan pemberian pakan $5 \%$ BB per setiap kali pemberian dengan frekuensi tiga kali.

Pengukuran kualitas air setiap 15 hari. Parameter kualitas air yang diukur adalah $\mathrm{DO}, \mathrm{CO}_{2}, \mathrm{NH}_{3}, \mathrm{pH}$, dan suhu.
Pengukuran kualitas air ini dilakukan selama 24 jam (pukul 08.00, 13.00, 18.00, 23.00, dan 05.00 Wib). Untuk mengetahui pertumbuhan ikan nila gift, dilakukan sampling dalam waktu per 15 hari selama pemeliharaan dua bulan.

Penelitian ini juga dilakukan dengan menggunakan dua perlakuan dan dua ulangan yaitu A1: kolam menggunakan aerasi air mancur ganda dan A2: kolam tanpa aerasi air mancur ganda (Lampiran 1.). Rancangan yang digunakan dengan membandingkan pada kedua kolam dengan menggunakan uji t (t-test). Hipotesis yang dipergunakan pada penelitian ini :

\section{Ho = Kolam tanpa aerasi air mancur ganda tidak dapat berpengaruh terhadap pertumbuhan ikan nila gift \\ H1 = Kolam menggunakan juga aerasi air mancur ganda berpengaruh terhadap pertumbuhan ikan nila gift.}

\section{HASIL DAN PEMBAHASAN}

Pada setiap perlakuan kenaikan pertumbuhan relatif terjadi perbedaan yang signifikan antara kolam aerasi air mancur ganda (A1) dan tanpa aerasi (A2). Pada kolam yang menggunakan aerasi (A1) nilai pertumbuhan relatif (\%) berat rata-rata pada akhir pemeliharaan $(1835,98 \%)$ dan tanpa aerasi (A2) (1352,29\%). Grafik Kecepatan Pertumbuhan Relatif (\%) Berat 
Rata-rata Ikan Nila Gift (Oreochromis

Dari grafik kecepatan pertumbuhan berat relatif (\%) pada Gambar 1, terlihat bahwa kedua perlakuan terus menerus mengalami pertumbuhan. Hal juga ini menunjukkan bahwa tahap pertumbuhan maksimum dari masing-masing kolam terjadi pada hari ke 30- 60 .

Perbandingan tingkat pertumbuhan antara kolam aerasi air mancur ganda (A1) dengan kolam tanpa aerasi (A2) yang terdapat pada Gambar 1, menunjukkan perbedaan yang sangat signifikan pada hari ke 30 sampai hari ke 60. Hal ini menunjukkan bahwa penggunaan suatu rekayasa terhadap lingkungan dengan menggunakan aerasi air mancur ganda yang memanfaatkan beda ketinggian yang niloticus) dapat dilihat pada Gambar 1.

bertujuan agar kebutuhan hidup ikan (faktor kimia) dapat terpenuhi. Secara tidak langsung dengan adanya aerasi air mancur ganda dapat menunjang untuk meningkatkan pertumbuhan ikan yang dipelihara dengan perbedaan yang sangat signifikan pada hari ke 30 sampai hari ke 60. Dengan kondisi di atas secara tidak langsung model aerasi memberikan suatu peranan dalam upaya guna meningkatkan produktivitas kolam ikan dibandingkan kolam tanpa aerasi. Menurut Erlania dkk (2010), kandungan oksigen dalam air merupakan faktor yang utama dalam menentukan daya dukung atau carrying capacity kolam ikan, di samping faktor lain seperti aliran air dan jenis ikan.

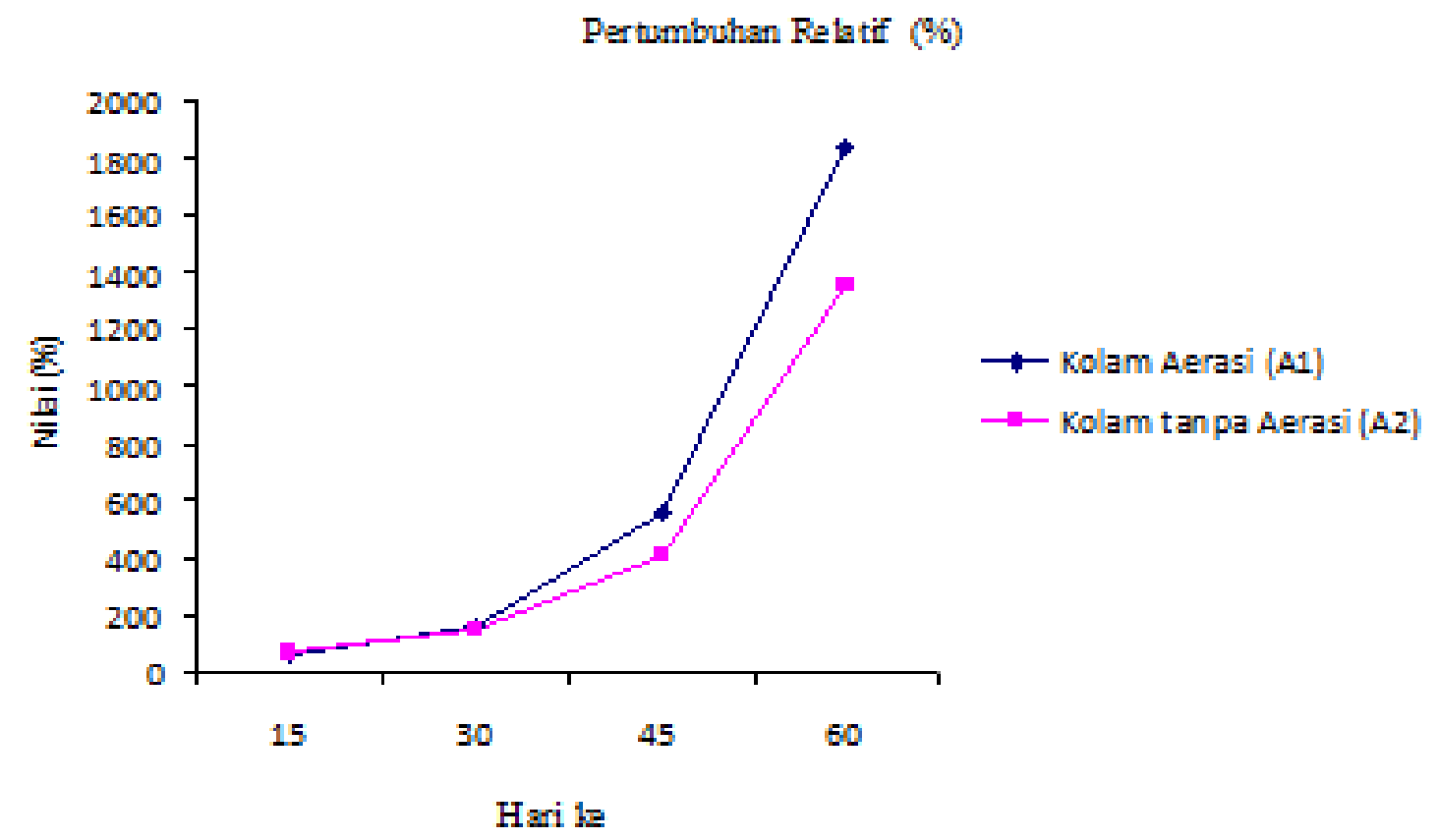

Gambar 1. Grafik kecepatan pertumbuhan relatif (\%) berat rata-rata individu ikan Nila Gift (Oreochromis niloticus) masing-masing perlakuan 
Banyaknya jumlah ikan dalam air memerlukan oksigen terlarut yang cukup, sehubungan kegiatan laju metabolisme, sehingga mengurangi kandungan oksigen dalam air (Diansari dkk, 2013).

Apabila akan dihubungkan dari perhitungan uji t, pertumbuhan terlatif antara kolam aerasi air mancur ganda (A1) dengan kolam tanpa aerasi (A2) adalah tidak berbeda nyata. Dalam hipotesis menunjukkan menerima $\mathrm{H}_{\mathrm{o}}$; tolak $\mathrm{H}_{1}$. Hal ini menunjukan bahwa yang berpengaruh nyata terhadap pertumbuhan ikan uji bukan karena oksigen terlarut melainkan faktor-faktor lain. Salah satu contohnya yaitu bisa disebabkan oleh kelimpahan fitoplankton maupun zooplankton sebagai pakan alami. Dengan kondisi banyaknya ketersediaan pakan alami dalam suatu perairan dalam ambang batas yang optimum dapat mendukung pertumbuahan bagi ikan yang dipelihara.

Pada Gambar 2 telah menunjukkan bahwa nilai suatu faktor kondisi akhir pemeliharaan ikan nila gift pada kolam aerasi air mancur ganda (A1) 3,66 dan pada kolam tanpa aerasi 3,53. Berdasarkan nilai ini, dapat dikatakan bahwa ikan nila gift yang dipelihara pada semua perlakuan adalah gemuk, berarti pertambahan berat lebih besar dari pada pertumbuhan panjang. Nilai ini termasuk pada kisaran yang dinyatakan Effendie (1997), bahwa faktor kondisi antara 1 - 3 untuk ikan yang badannya kurang pipih sedangkan ikan yang badannya agak pipih nilainya $2-4$.

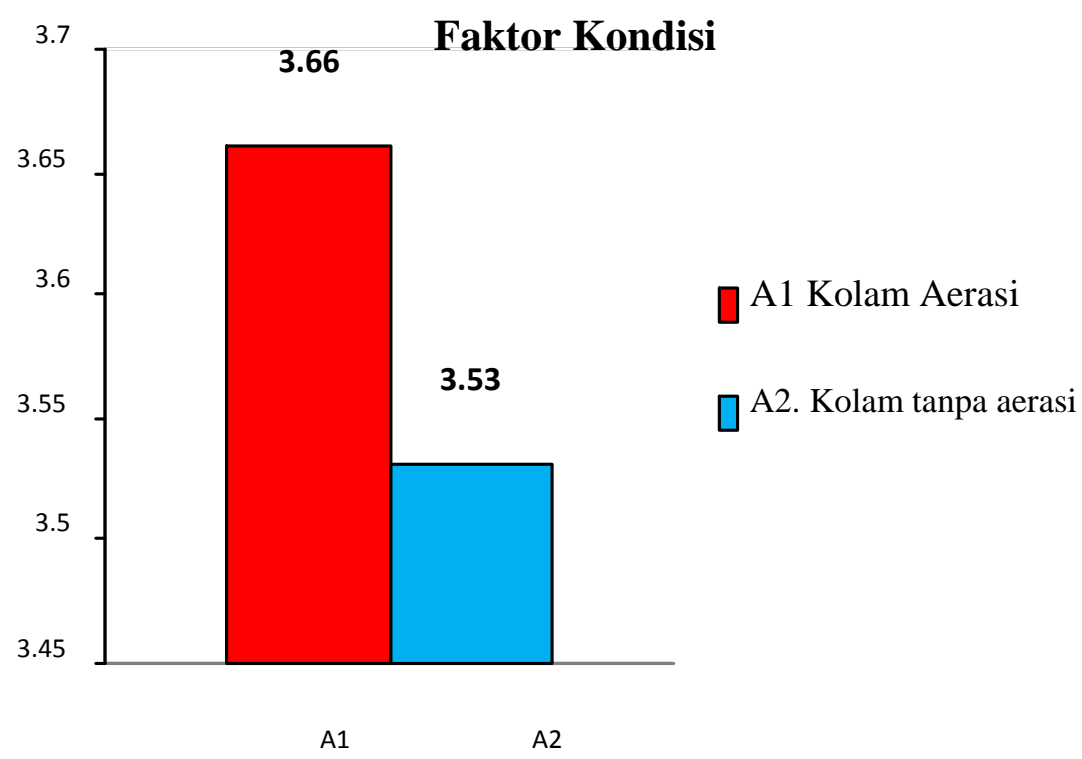

Gambar 2. Grafik nilai faktor kondisi ikan Nila Gift (Oreochromis niloticus) pada akhir pemeliharaan 
Apabila dihubungkan dari perhitungan uji

t, faktor kondisi antara kolam aerasi air mancur ganda (A1) dengan kolam tanpa aerasi (A2) adalah tidak berbeda nyata. Dalam hipotesis menunjukkan menerima Ho; dan tolak $\mathrm{H}_{1}$.

Nilai konversi makanan kolam cukup baik, karena semuanya di bawah nilai 2,0. Nilai terendah terdapat pada kolam dengan model aerasi air mancur ganda (A1) 1,49 dan kolam tanpa aerasi (A2) 1,73. Hal ini membuktikan bahwa dengan adanya aerasi model tersebut mampu menjadikan efisiensi pakan lebih tinggi. Menurut Handayani dan Hastuti (2002), konversi pakan tergantung pada oksigen terlarut, dengan ketentuan bahwa selama faktor kondisi lainnya optimum. Untuk lebih jelasnya dapat dilihat pada Gambar 3.
Apabila akan dihubungkan dari perhitungan uji t, konversi makanan antara kolam aerasi air mancur ganda (A1) dengan kolam tanpa aerasi (A2) adalah tidak berbeda nyata. Dari hasil hipotesis menunjukkan menerima Ho; tolak $\mathrm{H}_{1}$. Tidak adanya perbedaan yang nyata nilai konversi makanan antara kolam aerasi (A1) dengan kolam tanpa aerasi (A2) merupakan penyerapan makanan yang diberikan seimbang antara keduanya dengan ditandai nilai konversi makanan kurang dari 2. Semakin kecil nilai konversi makanan maka semakin bersar keuntungan yang didapat.

Nilai kelangsungan hidup ikan pada perlakuan kolam aerasi air mancur ganda untuk kolam (A1) (91,67\%), sedangkan perlakuan kolam tanpa aerasi (A2) $(89,17 \%)$.

\section{Konversi Makanan}

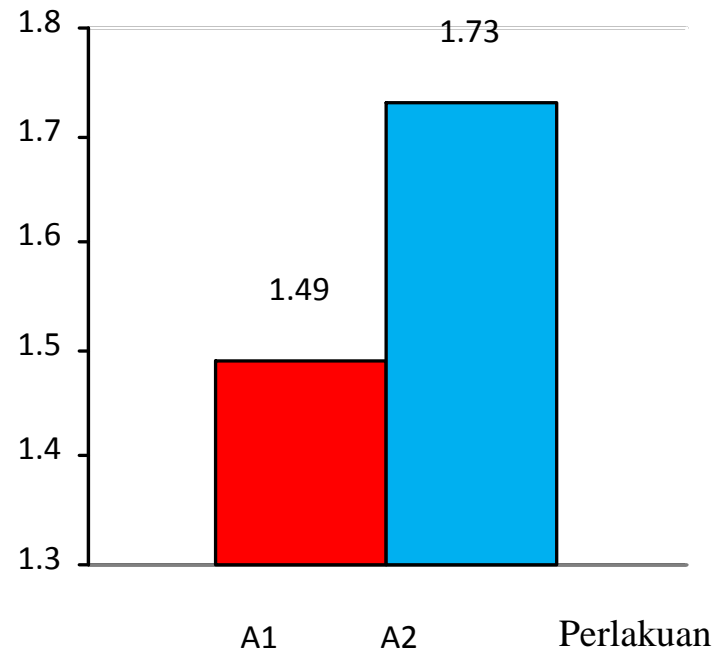

Gambar 3. Grafik nilai konversi makanan ikan Nila Gift (Oreochromis niloticus) pada akhir pemeliharaan. 


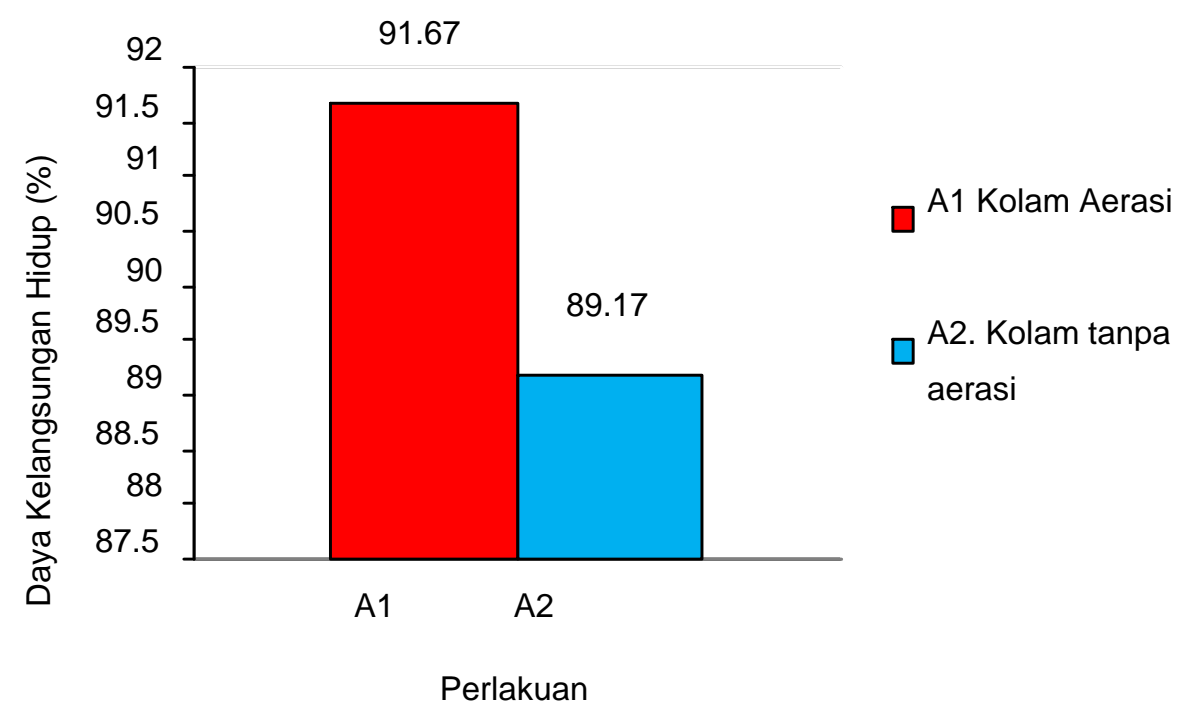

\section{Gambar 4. Grafik nilai kelangsungan hidup ikan Nila Gift (Oreochromis niloticus) antara perlakuan.}

Pada grafik Gambar 4. terlihat nilai kelangsungan hidup tertinggi terdapat pada kolam aerasi. Dari data uji t menunjukkan bahwa survival rate antara kolam kolam aerasi air mancur ganda dan kolam tanpa aerasi tidak berbeda nyata yaitu menerima $\mathrm{H}_{0}$; tolak $\mathrm{H}_{1}$. Jadi, dengan pemberian air mancur ganda tidak dapat menekan tingkat mortalitas ikan yang dipelihara.
Kadar oksigen terlarut terpantau pada penelitian ini merupakan parameter utama yang direkayasa dengan teknologi aerasi biaya rendah (air mancur ganda). Data dari kadar DO (Dissolved Oxygen) selama penelitian menunjukkan perbedaan yang sangat signifikan antara kolam aerasi (A1) serta kolam tanpa aerasi (A2) dan dapat dilihat terinci pada Gambar 5.

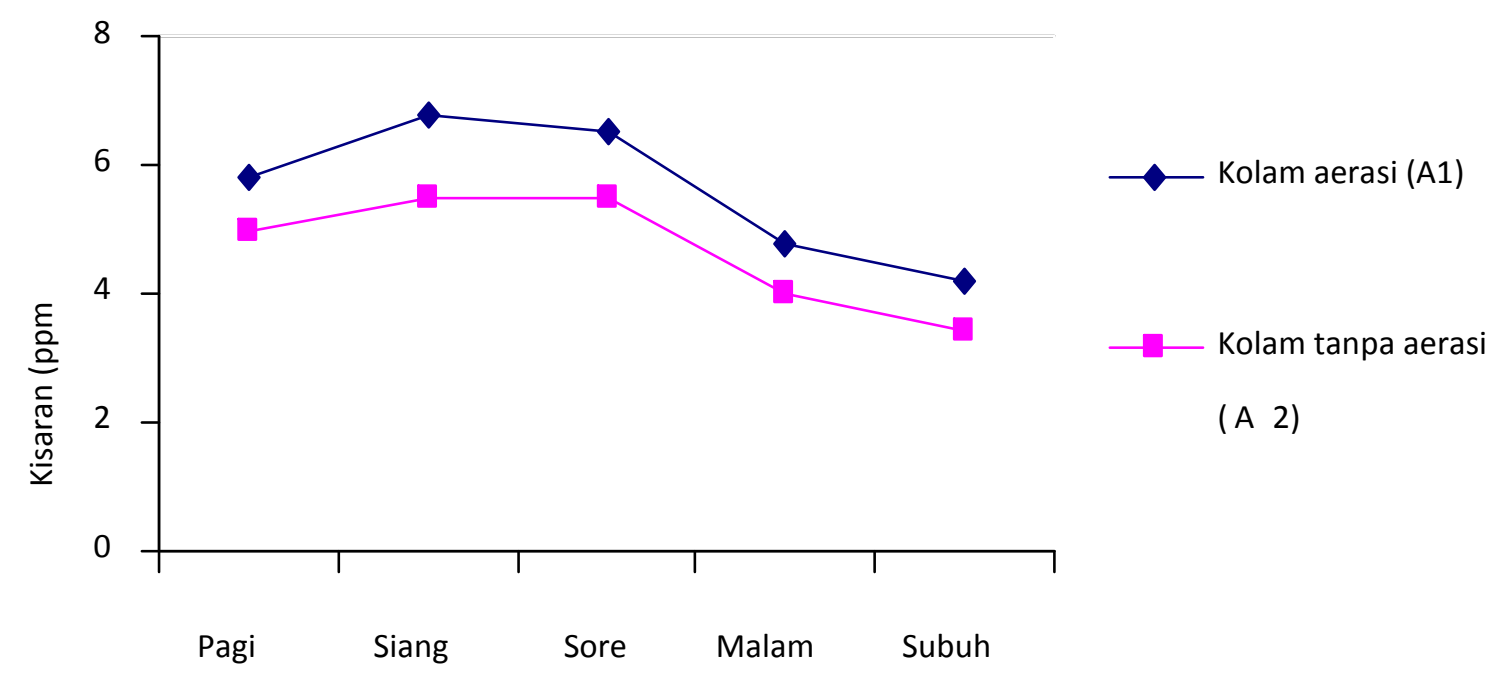

Gambar 5. Grafik rata-rata pengukuran oksigen terlarut selama pemeliharaan 
Pada Gambar 5 telah menunjukkan bahwa, dengan adanya suatu rekayasa lingkungan terhadap pemeliharaan yang menggunakan aerasi air mancur ganda (A1) akan dapat meningkatkan kandungan oksigen terlarut dalam air dibandingkan dengan kolam tanpa aerasi (A2).

Menurut kajian Jangkaru (1991), mengatakan bahwa oksigen terlarut untuk pemeliharaan ikan nila gift harus lebih dari 3 mg. $\mathrm{l}^{-1}$ sehingga ikan tumbuh secara optimal. Sedangkan menurut pengkajian Padmodiharto (2001) menyatakan perairan tempat pemeliharaan ikan nila gift sebesar 4,91 - 6,90 mg. $\mathrm{l}^{-1}$ memiliki kelangsungan hidup dari ikan tersebut sebesar 89,33\%. Dari hasil penelitian ini, kandungan oksigen terlarut pada kolam aerasi berkisar antara 4,2-6,8 mg. $\mathrm{l}^{-1}$ dan memiliki kelangsungan hidup sebesar 91,67\%.

Dari analisis regresi linier pengaruh oksigen terlarut terhadap pertumbuhan ikan, menunjukkan bahwa kolam aerasi air mancur ganda (A1) memberikan pengaruh terhadap pertumbuhan ikan nila gift. Hal ini dapat dilihat dari hasil persamaan regresi linier $\mathrm{Y}$ atas $\mathrm{X}$ adalah $\hat{y} \square \quad 6,67 \square$ $0,000043 x$. Dari hasil perhitungan nilai dari koefisien determinasi $\left(\mathrm{r}^{2}\right)$ ternyata didapatkan korelasi positif antara oksigen terlarut (X) dan pertumbuhan(Y). Berarti, meningkatnya kandungan oksigen terlarut meningkatkan pertumbuhan ikan

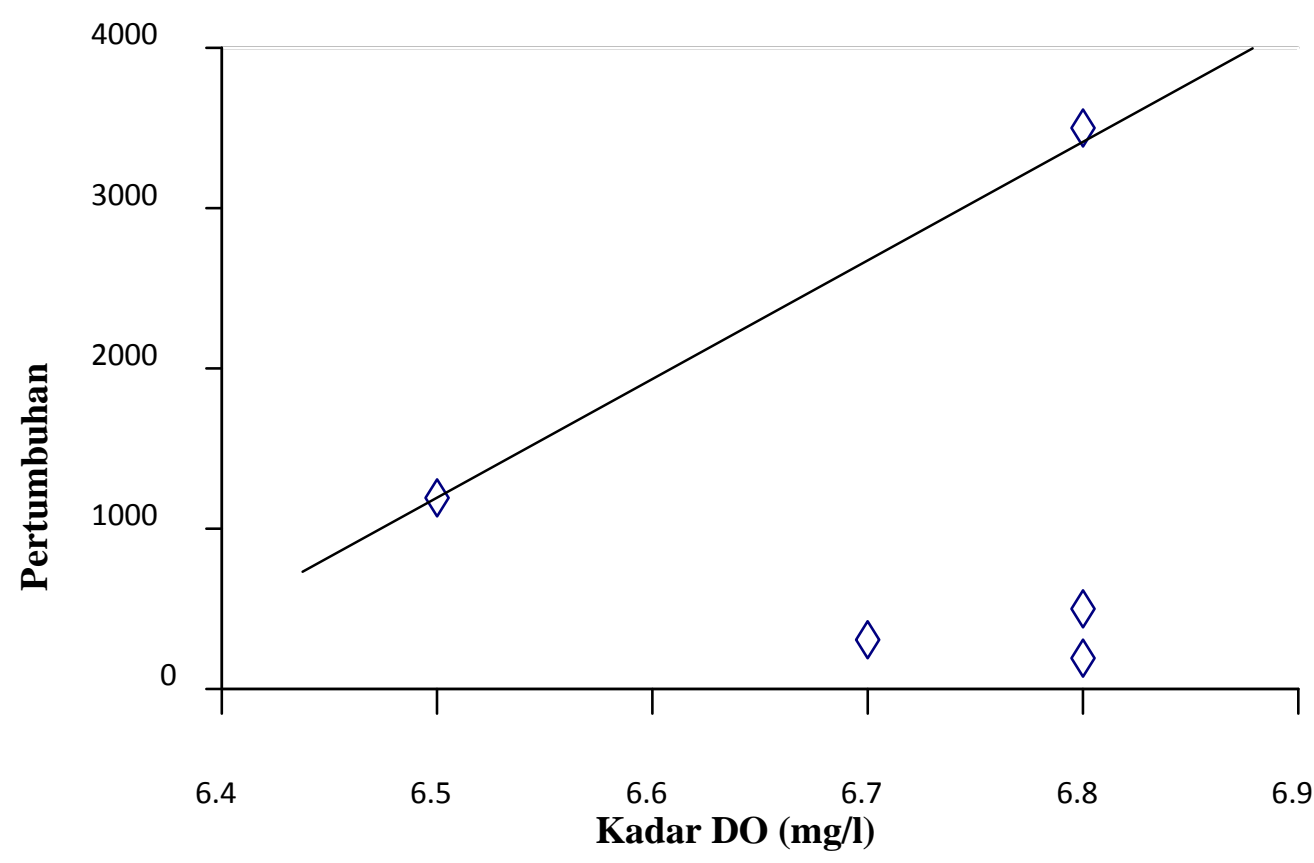

Gambar 6. Grafik analisis regresi antara oksigen terlarut (DO) dengan pertumbuhan 
Besarnya hubungan ditentukan oleh koefisien determinasi $\left(\mathrm{r}^{2}\right)=0,25$ atau $25 \%$, hal ini meningkatnya atau menurunnya tingkat pertumbuhan yang dipengaruhi oleh faktor oksigen sebesar $25 \%$ dan sisanya dipengaruhi oleh faktor-faktor lain. Data hasil regresi linier divisualisasikan pada Gambar 6

Walaupun hasil dari pada parameterparameter pengamatan menunjukan bahwa tidak berbeda nyata antara kolam aersai air mancur ganda (A1) dengan kolam tanpa Dari data yang diperoleh menunjukkan bahwa dengan adanya aerasi air mancur gandaguna meningkatkan kadar oksigen memberikan suatu pengaruh terhadap pertumbuhan ikan yang dipelihara.

Data amoniak yang diperoleh pada penelitian 0,05-0,1 ppm. Menurut Nugroho dkk (2012), batas konsentrasi $\mathrm{NH}_{3}$ yang baik sebaiknya tidak melebihi dari 0,3 mg. $1^{-1}$. Dari data yang diperoleh, maka dapat dinyatakan bahwa adanya kisaran amoniak perairan tempat penelitian masih dalam kisaran batas toleransi bagi ikan nila gift, sehingga kolam dapat digolongkan masih dalam kondisi baik

Kandungan karbondioksida pada kolam aerasi berkisar 1,65 - 3,8 mg. $\mathrm{l}^{-1}$, sedangkan kolam tanpa aerasi berkisar 2,75 - 5,1 mg. $\mathrm{l}^{-1}$. Menurut Arie (2001), kandungan $\mathrm{CO}_{2}$ yang aman harus kurang dari $5 \mathrm{mg} . \mathrm{l}^{-1}$ air. Dari hasil penelitian ini menunjukan bahwa kandungan $\mathrm{CO}_{2}$ dalam kolam masih dalam ambang batas yang tidak berbahaya (Monalisa \& infa, 2010).

Derajat keasaman $(\mathrm{pH})$ air selama penelitian ini 6-7. Menurut Asmawi (1984), bahwa untuk menciptakan suasana yang baik di perairan, $\mathrm{pH}$ air harus baik karena ikan hanya dapat bertahan terhadap goncangan $\mathrm{pH}$ 5-8. Jika keadaan ini terpenuhi, ikan akan dapat hidup dengan normal. Dengan demikian keadaan $\mathrm{pH}$ pada lokasi penelitian cukup menunjang kehidupan ikan nila gift

Hasil pengamatan suhu rata-rata: pagi $29,76{ }^{\circ} \mathrm{C}$, siang $31,57{ }^{\circ} \mathrm{C}$ dan sore $30,5{ }^{\circ} \mathrm{C}$. Suhu air keseluruhan pagi, siang dan sore hari berkisar 29,76-31,57 ${ }^{\circ} \mathrm{C}$. Kisaran suhu pada penelitian ini masih berada pada batas kisaran yang baik untuk ikan nila gift walaupun berbeda sedikit dengan kajian pendapat Yuliati dkk (2003) yang juga menyatakan bahwa untuk perkembangan nila gift, suhu $25-30{ }^{\circ} \mathrm{C}$.

Hasil analisa kelimpahan (sel.liter ${ }^{-1}$ ) plankton juga terdapat perbedaan yang signifikan antara kolam aerasi air mancur ganda dengan kolam tanpa aerasi. Untuk lebih jelasnya dapat disimak/dilihat pada Gambar 7. Dapat disimpulkan bahwa, dengan adanya aerasi air mancur ganda dapat meningkatkan suplai makanan alami dan mensuplai oksigen terlarut yang sangat berguna untuk tingkat kehidupan ikan. 


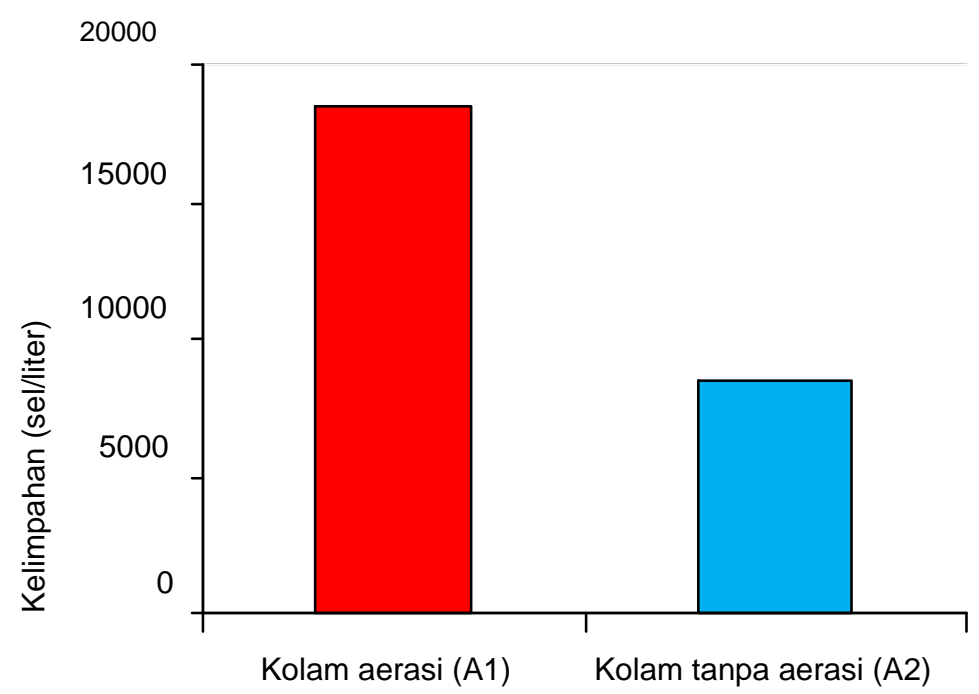

Perlakuan

Gambar 7. Grafik kelimpahan plankton pada media peneltian

\section{SIMPULAN DAN SARAN}

\section{Simpulan}

Rerata kecepatan dari pertumbuhan relatif berat (\%) ikan nila gift pada kolam aerasi air mancur ganda (A1) 1835,98\% dan pada kolam tanpa aerasi 1352,29 \%. Rerata faktor kondisi pada (A1) 3,66 dan (A2) 3,53. Rerata konversi makanan (A1) 1,49 dan (A2) 1,73. Rerata kelangsungan hidup (A1) $91,67 \%$ dan (A2) $89,17 \%$. Dari hasil uji nilai $\mathrm{t}$ semua parameter pengamatan menunjukkan tidak berbeda nyata, maka terima $\mathrm{H}_{\mathrm{o}}$; tolak $\mathrm{H}_{1}$. Dengan demikian penggunaan aerasi air mancur ganda pada kolam tidak berpengaruh nyata terhadap parameter yang diamati. Hasil analisa kualitas air secara keseluruhan pada kolam pemeliharaan masih berada dalam toleransi yang cukup baik untuk kehidupan ikan nila gift.

Teknologi aerasi air mancur ganda dengan investasi biaya rendah dapat dikembangkan oleh masyarakat dengan cara memanfaatkan energi gravitasi atau beda ketinggian dengan elevasi minimal 1,5 meter antara sumber air dengan daerah perkolaman ikan.

\section{Saran}

1. Teknologi Air mancur ganda ini dapat disosialisasikan sebagai suatu teknologi terapan yang dapat dikembangkan di masyarakat pembudidaya. 
2. Bagi siapa saja nantinya yang akan memodifikasi teknologi ini sangat diijinkan untuk penyempurnaan dan perkembangan fisheries engineering.

3. Penelitian lanjutan yang akan dilakukan untuk mengembangkan teknologi ini akan dirancang dengan penelitian multy fountain gravitation and modern multy fountain non-gravitation

\section{DAFTAR PUSTAKA}

Arie U. 2001. Pembenihan dan pembesaran nila gift. Penebar Swadaya. Jakarta. 128 halaman.

Diansari RR.V Rhossitha, Endang Arini dan Tita Elfitasari. 2013. Pengaruh kepadatan yang berbeda terhadap kelulushidupan dan pertumbuhan ikan nila (Oreochromis niloticus) pada sistem resirkulasi dengan filter zeolit. Jornal of Aquaculture Management and Technology. Vol 2 (3).

Effendie MI. 1997. Biologi perikanan bagian I. Fakultas Perikanan IPB, Bogor. 102 halaman.

Erlania R, Anjang B. Prasetio, dan J. Haryadi. 2010. dampak manajemen pakan dari kegiatan budidaya ikan nila (Oreochromis niloticus) di keramba jaring apung terhadap kualitas perairan Danau Maninjau. Prosiding Forum Inovasi Teknologi Akuakultur tahun 2010: 621-631 hal.

Handayani H dan S.D Hastuti. 2002. Budidaya perairan. Penerbit Bayu Media dan UMM Press. Malang. 200 halaman.

Jangkaru Z. 1991. Pembesaran ikan air tawar di berbagai lingkungan pemeliharaan. Penebar Swadaya. Jakarta. 96 halaman.

Monalisa S.S dan Infa Minggawati. 2010. Kualitas air yang mempengaruhi pertumbuhan ikan nila (Oreochromis sp.) di kolam beton dan terpal. Journal of Tropical Fisheries Vol 5 (2): 526-530

Nugroho RA, Lilik Teguh Pambudi, D. Chilmawati dan AHC Hadiutomo. 2012. Aplikasi teknologi aquapoic pada budidaya ikan air tawar untuk optimalisasi kapasitas produksi. Jurnal Saintek Perikanan Vol 8 (1): 46-51

Padmodiharto A. 2001. Efek pemberian pakan dosis minyak cengkeh terhadap tingkat kelangsungan hidup pada pengangkutan ikan nila gift. 30 halaman

Yuliati P, Tutik Kadarini, FN Rusmaedi. 2003. Pengaruh padat tebar terhadap pertumbuhan dan sintasan dederan ikan nila gift (Oreochromis niloticus) di kolam. Jurnal Iktiologi Indonesia Vol 3 (2): 63-67 
Lampiran 1. Konstruksi teknologi model air mancur ganda

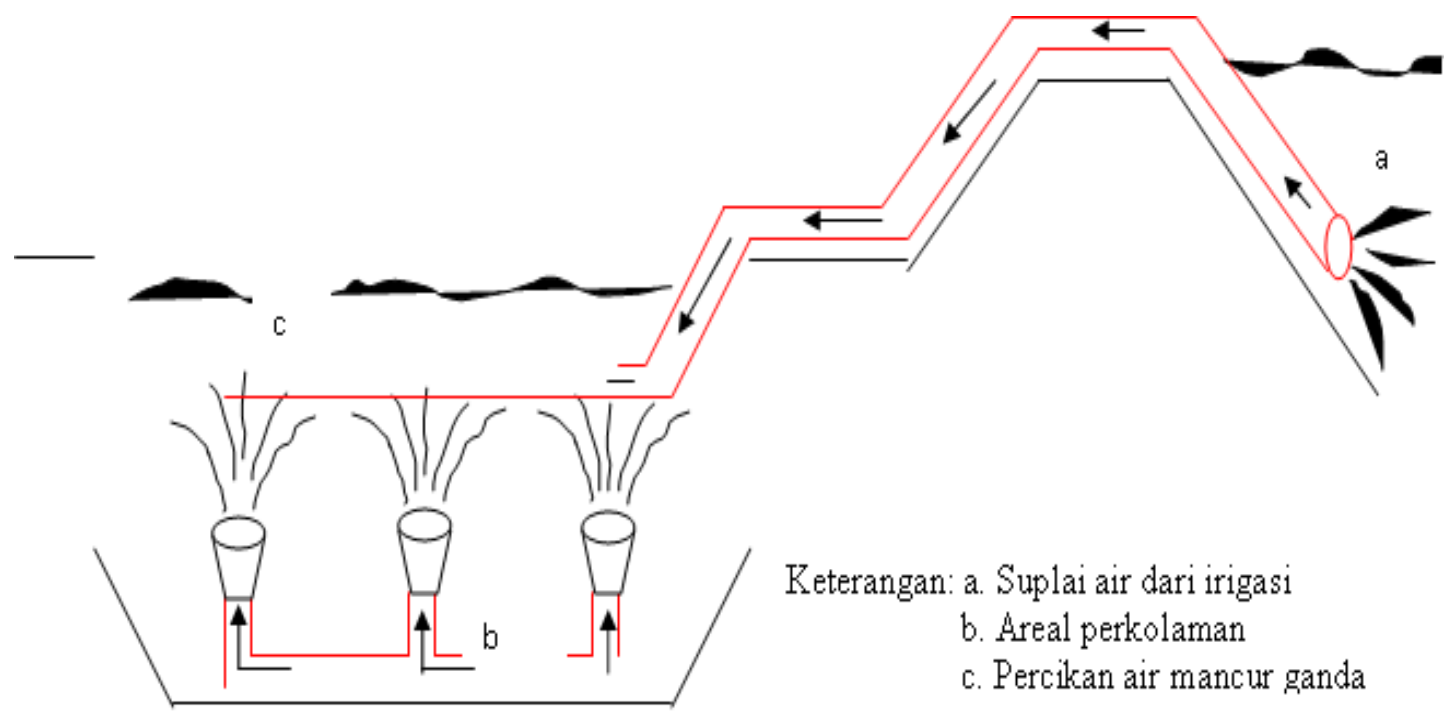

